УДК 349.2

DOI https://doi.org/10.32849/2663-5313/2020.6.15

Наталія Орлова,

канд. юрид. наук

асистент кафедри трудового права

Національного юридичного університету імені Ярослава Мудрого

\title{
ОСОБЛИВОСТІ ПРАВОВОГО РЕГУЛЮВАННЯ ОХОРОНИ ПРАЦІ НА ВОДНОМУ ТРАНСПОРТІ
}

Стаття присвячена дослідженню особливостей правового регулювання охорони прачі на водному транспорті. Проаналізовано найбільш поширені причини нещасних випадків на водному транспорті. Наголошується, шо наявність на борту судна необхіної кількості членів екіпажу впливає на виконання вимог стосовно дотримання робочого часу, недопущення перевантаження членів екіпажу судна роботою, надання належного часу відпочинку. Відзначається, що диферениіачія правового регулювання робочого часу і часу відпочинку прачівників водного транспорту здійснюється за трьома підставами: режим роботи судна, особливості конструкиї судна, характер трудових функиій плавскладу. Для того, шоб тривалість роботи екіпажу не перевишувала безпечно допустимого рівня, власник судна має визначити перелік необхідних $і$ достатніх функиій, які повинні виконуватися на судні під час майбутнього рейсу, функиї, які можна сумішати за умов нормальної експлуатаиї судна та за передбачених аварійних ситуащій на судні, а також мінімальний склад екіпажу, необхідний для безпечного виконання функиій за сумісниитвом. Відстоюється думка, що перевірка стану здоров'я працівників водного транспорту є однією з гарантій безпечного судноплавства. Рівень профпридатності суднових фахівців прямо і безпосередньо впливає на тривалість їхнього плавстажу без істотної зміни в стані тріади «здоров'я - працездатність - надійність», тому регулярне стеження за станом здоров'я прачівників є гарантією забезпечення особистої і колективної безпеки на водному транспорті. Доведено, що будь-яке судно має бути очолене капітаном і управлятися працівниками відповідної кваліфікаиї, які за станом здоров'я придатні для роботи на водному транспорті, а екіпаж за комплектацією має відповідати типу, розмірам і устаткуванню судна. Зроблено висновок, що специфіка організачї охорони прачі членів екіпажу під час рейсу полягає в тому, що ризик створюється не тільки виробничими факторами, а й природно-кліматичними умовами, можливістю інфікування y портах, загрозою потрапляння у піратський полон тощо. Обгрунтовано необхідність належного правового регулювання захисту життя $і$ здоров'я членів екіпажу як під час трудової діяльності, так i за межами роботи.

Ключові слова: водний транспорт, працівник водного транспорту, нещасний випадок, охорона праці, екіпаж судна, стан здоров'я.

Постановка проблеми. Процес праці потребує охорони від різних об'єктивних та суб'єктивних факторів. Важлива роль у цьому належить державі, яка закріплює на конституційному рівні забезпечення права працівників на охорону праці, а також розкриває його зміст у численних законах та підзаконних нормативно-правових актах. Основною метою законодавства про охорону праці є недопущення створення незадовільної організації виконання робіт, порушень трудової і виробничої дисципліни, порушень технологічного процесу, недоліків у навчанні, а також організації робочих місць і вимог безпеки під час експлуатації транспортних засобів.

Враховуючи те, що працівники водного транспорту постійно перебувають під впливом таких факторів, як природні умови (зміна погодних та кліматичних умов, зміна часових поясів, бортова та кільова хитавиця), виробничі умови (шум та вібрація, електромагнітне випромінювання, хімічне забруднення повітря); соціально-психологічні фактори (постійна готовність до виконання професійних обов'язків, монотонність професійної діяльності, дефіцит інформації, групова ізоляція та самотність, зниження рухової активності, додаткові загрози здоров'ю та навіть життю в окремих регіонах світу), цілком очевидно, що створення безпечних і здорових умов праці, мінімізація негативного впливу виробництва на здоров'я та життя працівників водного транспорту є нагальним та актуальним питанням, яке потребує чіткої регламентації.

Стан дослідження. Окремі аспекти охорони праці досліджували Л. Я. Гінзбург, Г. С. Гончарова, В. В. Жернаков, П. О. Ізуїта, Д. М. Кравцов, В. В. Лазор, 
Л. І. Лазор, Р. З. Лівшиць, Ю. П. Орловський, П. Д. Пилипенко, С. М. Прилипко, В. І. Прокопенко, О. І. Процевський, Н. М. Хуторян, Г. I. Чанишева, I. I. Шамшина, В. I. Щербина, О. М. Ярошенко, однак правове регулювання охорони праці на водному транспорті досі залишалося поза увагою у юридичній літеpaтурі.

Метою даної публікації є дослідження особливостей охорони праці на водному транспорті в аспекті вдосконалення правового регулювання.

Виклад основного матеріалу. За даними Управління безпеки на транспорті та технічного регулювання Міністерства інфраструктури України більшість (близько 80 \%) нещасних випадків на водному транспорті стається через організаційні причини (ті, що зумовлені організаційними недоліками роботи 3 охорони праці), тож видається доцільним розглянути найбільш поширені 3 них.

Однією з поширених причин нещасних випадків на водному транспорті $є$ недостатня кількість членів екіпажу під час рейсу. Поступове скорочення чисельності екіпажів суден призводить до зростання відповідальності та ускладнення функцій, виконуваних судновими спеціалістами, що у свою чергу призводить до накопичення втоми працівників. Стурбованість питанням втомленості моряків викликала прийняття спеціальної Резолюції Міжнародної морської організації від 04.11.1993 А.772(18) «Фактори втомленості при комплектуванні суден екіпажами та забезпеченні безпеки». Згідно 3 цією Резолюцією втомленість характеризується як зниження продуктивності праці людини, зниження фізичних та розумових здібностей та/або погіршення здатностей робити обгрунтовані висновки. Втома може бути викликана такими факторами, як довготривалий період розумової та фізичної активності, неповноцінний відпочинок, несприятливий вплив навколишнього середовища, фізіологічні фактори та/або стрес тощо Одним 3 ефективних засобів вирішення проблеми накопичення втоми працівників водного транспорту має стати визначення та перевірка наявності мінімального складу екіпажу залежно від призначення та розмірів судна.

Важливість комплектації суден нормальною кількістю екіпажу підтверджена положеннями Конвенції Про мінімальні норми на торговельних суднах № 147 від 13.10.1976: кожна держава повинна мати законодавство та правила, які встановлюють для зареєстрованих на його території суден норми без- пеки, включаючи норми відносно кваліфікації, тривалості робочого часу і комплектації екіпажу з метою забезпечення безпеки для життя на борту судна [1].

Будь-яке судно має бути очолене капітаном і офіцерами відповідної кваліфікації у сфері судноводіння, навігації, зв'язку, суднових машин і устаткування, а екіпаж за кваліфікацією та чисельністю має відповідати типу, розмірам і устаткуванню судна [2]. Наявність на борту судна необхідної кількості членів екіпажу впливає на виконання вимог стосовно дотримання робочого часу, недопущення перевантаження членів екіпажу судна роботою, надання належного часу відпочинку. Раціональне поєднання робочого часу з часом відпочинку дає змогу ефективно використовувати здатність людини до продуктивної праці, відтворювати фізичні та психологічні характеристики працівника, а також комплексно застосовувати виробничі потужності.

Диференціація правового регулювання робочого часу і часу відпочинку працівників водного транспорту здійснюється за трьома підставами (за трьома об'єктивними факторами): режим роботи судна, особливості конструкції судна, характер трудових функцій плавскладу.

Стосовно першої підстави - режими робочого часу i часу відпочинку на водному транспорті встановлюються залежно від режиму роботи судна і поділяються на режим робочого часу у період застосування судна за призначенням (у період рейсу) та режим робочого часу у період ремонтних робіт. В основі організації праці на суднах, що знаходяться у режимі застосування за призначенням, лежить цілодобова вахтова служба. Вахта - це, з одного боку, кількісний показник робочого часу плавскладу, 3 іншого - форма організації праці. Вахта має бути організована таким чином, щоб втома як командного, так і рядового складу не впливала на ефективність несення вахти. Служба має бути організована таким чином, щоб особовий склад першої під час відходу в рейс і наступних змінних вахт одержував достатній відпочинок і був придатний до несення вахти у всіх інших відношеннях [3]. Крім того, чергування в період стоянки суден у портах можливо прирівняти до вахти, у зв'язку з чим необхідним є приведення правового регулювання чергувань у відповідність до норм про вахтову службу.

Стосовно другої підстави - особливості конструкцій окремих суден не дозволяють мати достатньої кількості житлових приміщень для розміщення суднового екіпажу, відповідно, слід законодавчо закріпити 
можливість встановлення на цих суднах збільшення тривалості змін, а також заміни, наприклад, режиму тризмінної роботи на режим двозмінної.

Стосовно третьої підстави - режим робочого часу встановлюється залежно від виконуваних плавскладом трудових функцій: наприклад, у період роботи судна за призначенням він різний для командного і рядового складу

Особливість правового регулювання понаднормових робіт на водному транспорті у період застосування судна за призначенням полягає в тому, що виконання цих робіт не обмежене граничними нормами. Отже, є необхідність визначення кола осіб, що можуть бути залучені до додаткових, «авральних» робіт, а також визначення тривалості такої роботи на добу. Крім того, постійно зростає тривалість рейсів, що зумовлює спеціальне нормування термінів рейсів і безперервного перебування суднових екіпажів у морі. Терміни безперервного перебування в морі можна диференціювати залежно від типу суден і районів плавання. При цьому не можна не виділити такі фактори, як оснащеність судна, сучасність устаткування, сезон перебування в морі.

Умови праці і проживання плавскладу характеризуються дією цілого комплексу чинників, вираженість і набір яких може значно змінюватись залежно не лише від професії і типу судна, але й від динамічно змінних умов плавання. Цілодобовий вплив на моряків фізико-хімічних, медико-біологічних і соціально-психологічних факторів дозволяє вважати цю працю важкою та напруженою [4, с. 4]. Більшість факторів впливають на членів екіпажу як безпосередньо на робочих місцях, у робочих зонах, так і під час їхнього відпочинку, сну, проведення вільного часу.

Основні питання встановлення та застосування режимів робочого часу і часу відпочинку регулюються правилами внутрішнього трудового розпорядку, графіками змінності та іншими локальними актами. Але у зв'язку з тим, що працівники водного транспорту є спеціальними суб'єктами трудового права, доречно застосовувати до працівників цієї категорії індивідуальний підхід, який найкраще зафіксувати у відповідних трудових договорах. Крім того, умови їхньої праці мають специфічний характер, а до трудових правовідносин з участю працівників-моряків можуть застосовуватися норми міжнародного права i національного законодавства іноземних держав. Чинне законодавство про робочий час і час відпочинку має слугувати двом основним цілям: по-перше, повному, раціональному та ефективному використанню трудового потенціалу; по-друге, захисту працівників від надмірних перевантажень, забезпеченню відновлення їхньої працездатності, збереженню її протягом тривалого часу. Задля досягнення зазначених вище цілей необхідним є дотримання вимоги про наявність мінімального складу екіпажу на судні.

Відповідно до ст. 50 Кодексу торговельного мореплавства України мінімальний склад екіпажу, за якого дозволяється вихід судна в море, залежить від району плавання, призначення та типу судна відповідно до чинного законодавства України [5]. Йдеться не про зменшений «екстремальний» склад, а про екіпаж, розрахований для нормальної експлуатації судна 3 повним дотриманням усіх вимог з безпеки судноплавства, трудового законодавства, а також з урахуванням ризиків, пов'язаних з людським фактором. При цьому перевищення фактичної чисельності суднового екіпажу в рейсі так само ускладнює його розміщення в житлових приміщеннях, що призводить до зниження рівня комфортності та збільшення «трудовитрат» на побутове обслуговування.

Згідно 3 Порядком визначення мінімального складу екіпажу судна, затвердженим Наказом Міністерства інфраструктури України від 10.11.2014 № 575, мінімальним складом є мінімальна кількість осіб командного складу та суднової команди, які можуть у будь-який час експлуатації гарантувати безпечне управління судном [6]. Свідоцтво про мінімальний склад екіпажу та суднова роль (документ, у якому зазначаються відомості про кількість і склад екіпажу) є основними документами, які повинно мати будьяке судно.

3 метою забезпечення сталої роботи екіпажу в обгрунтуванні і розрахунках судновласник повинен врахувати кваліфікацію членів екіпажу, необхідну для виконання покладених на них обов'язків, а також мінімальну кількість кваліфікованих членів екіпажу, необхідних для безпечного виконання функцій за сумісництвом. Згідно 3 ч. 2 п. 9 Інструкції щодо застосування постанови Ради Міністрів СРСР Про порядок і умови суміщення професій (посад) № 1145 від 04.12.1981 зменшення чисельності працівників у результаті суміщення професій (посад) не може служити підставою для зміни встановленого підприємством, установою, організацією ліміту чисельності та затвердженого для них штатного розкладу.

Ураховуючи, що виконання додаткової роботи у вільний від основної роботи час вимагає від працівника водного транспорту 
більшого навантаження (фізичного, морального, психічного), обмеження сумісництва потребує чіткого врегулювання шляхом включення додаткових положень до змісту колективних договорів, як це передбачено у ч. 2 ст. 21 Кодексу законів про працю. Для того, щоб тривалість роботи екіпажу не перевищувала безпечно допустимого рівня, власник судна має визначити перелік необхідних і достатніх функцій, які повинні виконуватися на судні під час майбутнього рейсу, функції, які можна суміщати за умов нормальної експлуатації судна та за передбачених аварійних ситуацій на судні, а також мінімальний склад екіпажу, необхідний для безпечного виконання функцій за сумісництвом.

Кожне судно має бути укомплектоване достатнім за кількістю екіпажем високого рівня кваліфікації. Працівники, які безпосередньо забезпечують безпеку руху транспортних засобів, повинні мати відповідну професійну підготовку і за станом здоров'я бути здатними якісно виконувати свої обов'язки. Ці працівники, а також працівники, які зазнають впливу шкідливих і небезпечних умов праці, повинні проходити у встановленому порядку медичні обстеження [7].

Система стандартів безпеки судноплавства прямо залежить від стану здоров'я екіпажу, кожного працівника на судні. У зв'язку 3 тим, що робота на водному транспорті характеризується наявністю травмуючих факторів, екстремальних та стресогенних чинників, що виникають спонтанно, і тому потребує від особи певних фізичних та психофізіологічних якостей, перевірка належного стану здоров'я працівників є однією з гарантій безпечного судноплавства.

За вимогами, що пред’являються до стану здоров'я і психофізіологічного стану працівників, залежно від важливості функцій, що виконуються ними на судні, особи, які проходять медичний огляд, об'єднуються у професійні групи: до першої групи віднесено осіб, професійна діяльність яких не пов'язана 3 питаннями безпеки (слюсарі, токарі, дизелісти самохідних кранів, кочегари тощо), до другої групи - осіб, які виконують рішення, пов'язані з безпекою під час плавання (електрики, машиністи, маячні служники тощо), до третьої групи - осіб, які приймають рішення, пов'язані з безпекою під час плавання (капітани, помічники капітанів, механіки, помічники механіка, начальники радіостанцій та ін.) [8]. В основі такого розподілу фахівців водного транспорту за професійними групами - ступінь соціальної небезпеки їхньої професійної діяльності (ст. 31 «Обов'язкові медичні огляди» Основ законодавства України про охорону здоров’я).

Для виявлення непридатних кандидатів під час профвідбору мають бути враховані такі психологічні протипоказання, як розсіяна увага, підвищена конфліктність, недостатня психічна стійкість, схильність до паніки і схильність до ризику. Усе це не дасть можливості претенденту належним чином жити на судні і виконувати свої функції, особливо в небезпечних ситуаціях [9, с. 115]. Професійний психологічний відбір важливий не тільки для забезпечення ефективності трудової діяльності та безпеки, але й може допомогти самій людині в збереженні фізичного і душевного здоров'я. Недоліком правового регулювання у сфері охорони праці на річковому та морському транспорті є відсутність системного медичного спостереження за працівниками, які повертаються 3 рейсів: у міжрейсовий період перевірка стану здоров'я моряків не здійснюється, підготовка до наступного рейсу не проводиться. У зв'язку з тим, що після рейсу не здійснюється оцінка стану здоров'я працівників-моряків, немає динамічного спостереження за зміною їхнього здоров’я. Видається необхідним встановлення диспансерного спостереження за здоров'ям працівника водного транспорту хоча б у перші тижні після рейсу з метою запобігання різного роду захворюванням.

Захворюваннями та вадами, які протипоказані для роботи на суднах, є внутрішні хвороби (ішемічна хвороба серця, хвороби міокарда, ендокарда, перикарда, важкі форми цукрового діабету, хронічні захворювання легенів, нирок тощо), нервові та психічні хвороби (розумова відсталість, шизофренія, невротичні розлади тощо), хірургічні хвороби, захворювання очей, хвороби вуха, горла, носа, хвороби шкіри. Конвенцією Про зобов'язання судновласників у разі хвороби, травми або смерті моряків № 55 від 24.10.1936 передбачено, що судновласник несе зобов'язання у разі хвороб і травм, які виникли в період між датою початку роботи і датою закінчення строку найму, та смерті, яка сталася через таку хворобу або травму, однак при цьому національним законодавством може передбачатись, що судновласники не є відповідальними за хворобу або смерть, безпосередньо спричинену хворобою, якщо особа, яка влаштовується на роботу, відмовилася пройти медичний огляд на момент зарахування на службу [10]. Таке положення суперечить нормам Конвенції про медичний огляд моряків № 73 від 29.06.1946, згідно з якою ніхто не може бути прийнятий на роботу на судно, якщо не подасть посвідки, що підтверджує придатність до роботи [11]. 
Крім того, положення ст. 46 Кодексу законів про працю України також видаються суперечливими: роботодавець може відсторонити від роботи працівника, який ухиляється від проходження обов'язкового медичного огляду у встановленому порядку; при цьому відсторонення не є обов'язком роботодавця - лише правом, що представляється неправильним, особливо у галузі водного транспорту. Видається, праця на водному транспорті виключає можливість здійснення трудової функції без перевірки відповідності стану здоров'я працівника виконуваній роботі, і тому проходження медичних оглядів працівників даної категорії є обов'язковим, у зв'язку з чим вищезазначені норми потребують внесення відповідних змін.

Таким чином, з вищевикладеного видно, що держава використовує світовий досвід організації роботи з покращення умов та безпеки праці на водному транспорті, вдосконалює національну нормативну базу з питань охорони праці, однак окремі положення законодавства потребують взаємоузгодження та доопрацювання. Рівень профпридатності суднових фахівців прямо і безпосередньо впливає на тривалість їхнього плавстажу без істотної зміни в стані тріади «здоров'я - працездатність - надійність», тому регулярне стеження за станом здоров'я працівників є гарантією забезпечення особистої і колективної безпеки на водному транспорті.

Будь-яке судно має бути очолене капітаном і працівниками відповідної кваліфікації у сфері судноводіння, навігації, зв'язку, суднових машин і устаткування, які за станом здоров'я придатні для роботи на водному транспорті, а екіпаж за чисельністю має відповідати типу, розмірам і устаткуванню судна.

Питання диференціації у правовому регулюванні охорони праці членів екіпажу на водному транспорті не можна визнати повністю дослідженим без аналізу значних особливостей. Характеристика життя і життєдіяльності екіпажу на борту судна передбачає комплекс умов, що інтегруються в єдине поняття, кваліфіковане як суднове середовище [12, с. 10]. Специфіка організації охорони праці членів екіпажу під час рейсу полягає у тому, що ризик створюється не тільки виробничими факторами, а й природно-кліматичними умовами, можливістю інфікування у портах, загрозою потрапляння у піратський полон тощо.

Особливості трудової діяльності осіб у період рейсів насамперед зумовлені необхідністю тривалого перебування на борту водного транспортного засобу. Фактори, що діють на організм працівників протягом всього періоду рейсу в умовах обмеженого об'єкта (судна), можуть викликати зміни в стані їхнього здоров'я. Одним із найбільш специфічних факторів впливу є зміна природно-кліматичних умов під час рейсів у різні точки світу.

Так, під час тривалих арктичних рейсів часто у членів екіпажу фіксується напруга вегетативного тонусу, підвищується збудливість у психоемоційній сфері, збільшується кількість надмірних метеопатичних реакцій на кліматичні умови [13, с. 47; 14, с. 46]. Такі зміни реактивності можуть спровокувати виникнення або загострення соматичних захворювань, пов'язаних з дихальною, нервовою, травною системами, а також обміном речовин $[15$, с. $67 ; 16$, с. $12 ; 17$, с. 58$]$. Під час роботи в умовах Півночі низька температура повітря у поєднанні з підвищеною вологістю може призвести до порушень функцій опорно-рухового апарату, що значно знижуе працездатність.

У разі здійснення морських рейсів у тропічні широти на організм працівників також впливають специфічні природні умови. У цих районах клімат жаркий та вологий. Крім того, безсумнівним несприятливим фактором тут $€$ інтенсивна інсоляція, впливу якої значною мірою піддається палубна команда. У процесі адаптації до жаркого клімату у людей спостерігається підвищення температури тіла, почастішання пульсу і дихання, Зниження артеріального тиску, відзначається пригнічення секреторної і моторної функції шлунково-кишкового тракту. Дослідженнями доведено наявність зміни у моряків вітамінного, вуглеводного, водно-сольового і білкового обміну [18, с. 140]. Крім того, під час плавання у низьких широтах несприятливі збої функцій організму найчастіше бувають виражені більшою мірою, ніж під час рейсів у північні моря [19, с. 27].

Суворі природно-кліматичні умови у поєднанні з виконанням складних професійних обов'язків пред'являють підвищені вимоги до функціональних систем організму працівників водного транспорту. Нормативного закріплення у зв'язку з цим потребують питання ранньої діагностики так званих «передхворобливих» (преморбідних) станів у осіб, що працюють в екстремальних умовах, проведення системних медико-реабілітаційних заходів з метою відновлення ослаблених функцій організму працівників.

Крім того, члени екіпажу піддаються ризику захворювання більш ніж у 90 країнах по всьому світі. Найчастіше це Африка, Азія i американський континент. Серед небезпечних хвороб, якими може бути інфікований член екіпажу під час рейсу, - жовта 
лихоманка (ризик захворювання у разі перебування у субтропічних районах Африки, Центральної і Південної Америки), малярія (трапляється у тропіках та субтропіках), лихоманка денге (тропічна інфекція), гепатит А і В, поліомієліт (ризик захворювання у районах Африки та Азії) тощо. Останніми роками стурбованість також викликають часті випадки захворювань від лихоманки Ебола і вірусу Зика.

На практиці на суднах часто відсутні комплекти протималярійних препаратів, засобів захисту шкіри (репелентів); у припортових містах відсутні базові аптеки для постачання на судна медикаментів; моряки перед виходом у рейс не завжди проінформовані про медичні проблеми у портах відвідування. До того ж, у законодавстві відсутня норма, згідно з якою командний склад перед рейсом має пройти інструктаж стосовно медичних проблем залежно від району плавання (не раз на кілька років, під час отримання сертифіката на право надання медичної допомоги, а й перед кожним рейсом, як додаткове навчання).

Останніми роками небезпечного поширення набуло міжнародне піратство, результатом якого $є$ загроза потрапляння у піратський полон. Сьогодні піратство являє реальну небезпеку для мореплавання й насамперед посягає на права кожної людини на життя, свободу й особисту недоторканість.

Відповідно до ст. 101 Конвенції Організації Об'єднаних Націй з морського права від 10.12.1982 піратством є будь-яка з перерахованих нижче дій: а) будь-який неправомірний акт насильства, затримання або будьякий грабіж, який вчиняється в особистих цілях екіпажем чи пасажирами судна або літального апарату, що знаходяться у приватній власності, і спрямований у відкритому морі проти іншого судна або проти осіб чи майна, які перебувають на його борту; проти будь-якого судна, осіб або майна в місці поза юрисдикцією будь-якої держави; б) будьякий акт добровільної участі у використанні будь-якого судна за обставин, в силу яких судно є піратським судном; в) будь-яке діяння, що є підбурюванням або свідомим сприянням здійсненню дій, передбачених у підпунктах а) і б) [20].

Сучасне піратство за методами, які використовують морські злочинці, можна умовно поділити на два види: «сомалійське» та «індонезійське». Індонезійське піратство характеризується нападами озброєних банд на торговельні судна у відкритому морі або акваторіях портів 3 метою захоплення суднової каси та цінних речей. Сомалійські ж пірати є озброєними угрупуваннями, метою яких $\epsilon$ захоплення судна та заручників і вимагання викупу за них.

Основні проблеми в боротьбі з піратством полягають у фінансових складнощах більшості прибережних держав третього світу, неможливості постійного перекриття районів піратства наявною кількістю кораблів, катерів і літальних апаратів (патрулювання сьогодні залишається одним із найбільш ефективних заходів у боротьбі з піратством), наданні прибережними державами та судовласницькими компаніями хибної статистичної інформації про напади на судна, неузгодженості правових норм і актів, що визначають режим прибережних районів тощо.

Міжнародно-правова позиція України у сфері боротьби з піратством виражена у їі активній участі в ратифікації чинних міжнародно-правових актів, в імплементації в українське законодавство положень відповідних міжнародно-правових актів. Так, Україною була ратифікована Міжнародна конвенція з охорони людського життя на морі 1974 р. (СОЛАС-74), яка є, мабуть, найважливішою з усіх міжнародних угод з безпеки торговельного мореплавства, Конвенція Про боротьбу з незаконними актами, спрямованими проти безпеки морського судноплавства від 10.03.1988, Протокол про боротьбу 3 незаконними актами, спрямованими проти безпеки стаціонарних платформ, що розташовуються на континентальному шельфі від 10.03.1988; у грудні 2002 року був прийнятий Міжнародний кодекс з охорони суден та портових засобів (Кодекс ОСПЗ) тощо. Кодекс торговельного мореплавства України також містить положення, згідно з якими капітан у разі небезпеки зобов'язаний застосовувати всі необхідні і можливі заходи для порятунку людей, що перебувають на судні, і не допустити захоплення судна, документів, вантажу й іншого майна, що на ньому знаходяться (ст. 62). Статтею 258 Кримінального кодексу України передбачено відповідальність за здійснення терористичного акту. Крім того, 6 вересня 2017 року в Україні утворено Морську адміністрацію (Державна служба морського та річкового транспорту України) - центральний орган виконавчої влади України, який реалізує державну політику у сферах морського та річкового транспорту, торговельного мореплавства, судноплавства на внутрішніх водних шляхах, навігаційногідрографічного забезпечення мореплавства, а також у сфері безпеки на морському та річковому транспорті.

Національна правова база боротьби з морським піратством потребує удосконалення. 
На практиці, як правило, боротьба з піратством обмежується звільненням заручників шляхом викупу, що спричиняє нові злочини. Тому забезпечення безпеки судноплавства, збереження життя та здоров'я працівниківморяків вимагає консолідації зусиль як на міжнародному, так і на національному рівні, усунення підгрунтя для такого діяння, вироблення комплексу заходів проти піратства і тероризму.

\section{Висновки}

Таким чином, будь-яке судно має бути очолене капітаном і працівниками відповідної кваліфікації у сфері судноводіння, навігації, зв’язку, суднових машин і устаткування, які за станом здоров'я придатні для роботи на водному транспорті, а екіпаж за чисельністю має відповідати типу, розмірам і устаткуванню судна.

Специфіка роботи на водному транспорті характеризується не тільки необхідністю надання належних умов праці та дотримання безпеки під час трудової діяльності працівників водного транспорту, а й необхідністю належного правового регулювання захисту життя і здоров'я членів екіпажу як під час трудової діяльності, так і за межами роботи.

\section{Список використаних джерел:}

1. Конвенція МОП 147 про мінімальні норми на торговельних суднах 1976 року : Конвенція, Міжнародний документ від 29.10.1976 № 147. Офіиійний вісник України. 2007. № 92. Ст. 3387.

2. Конвенція Організації Об'єднаних Націй 3 морського права : Конвенція, Міжнародний документ від 10.12.1982. Відомості Верховної Ради України. № 728-14. Ст. 90-92.

3. Міжнародна конвенція про підготовку i дипломування моряків та несення вахти 1978 року : Конвенція, Міжнародний документ від 07.07.1978. Офіиійний вісник Украӥни. 2009. № 60. Ст. 2148

4. Мацеевич Л. М. Охрана здоровья моряков. Москва : Транспорт, 1986.200 с.

5. Кодекс торговельного мореплавства України : Кодекс України; Закон, Кодекс від 23.05.1995 № 176/95-ВР. Відомості Верховної Ради Украйни. 1995. № 47. Ст. 349.

6. Про затвердження Порядку визначення мінімального складу екіпажу судна : наказ Міністерства інфраструктури України від 10.11.2014 № 575. Офіиійний вісник України. 2014. № 99. Ст. 2926.
7. Про транспорт : Закон України від 10.11.1994 № 232/94-ВР. Відомості Верховноі Ради України. 1994. № 51. Ст. 446.

8. Про затвердження Правил визначення придатності за станом здоров'я осіб для роботи на суднах : наказ Міністерства охорони здоров'я України від 19.11.1996 № 347. Офіиійний вісник України. 1997. № 14. Ст. 99.

9. Бойович В., Прусс В. М. Международноправовые стандарты квалификации в морской отрасли. Спеииальный выпуск научно-аналитического журнала «Митна справа». Одеса, 2001. C. 114-122.

10. Конвенція про зобов'язання судновласників у разі хвороби, травми або смерті моряків № 55 : Конвенція, Міжнародний документ від 24.10.1936 № 55. URL: https://zakon.rada.gov.ua/ laws/show/993_156 (дата звернення: 15.05.2020).

11. Конвенція про медичний огляд моряків N 73 : Конвенція, Міжнародний документ від 29.06.1946 № 73. URL: http://zakon2.rada.gov.ua/ laws/show/993 129 (дата звернення: 15.05.2020).

12. Галанкин Л. Н. Инновационное развитие медицинского обеспечения на морском судне. Вестник Государственного университета морского и речного флота имени адмирала С. О. Макарова. 2014. № 2 (24). С. 9-16.

13. Жеглов В. В., Семенов Ф. М., Касаткин В. И. Повышение устойчивости моряков к заболеваниям. Морской сборник. 2012. № 7 (1984). C. 47-51.

14. Стрелкова О. В. Психологические аспекты профессиональной деятельности моряков. Becmник Балтийского федерального университета им. И. Канта. 2010. № 5. С. 45-51.

15. Андреева Е. А. Функциональное состояние респираторной системы у больных пневмониями моряков Северного бассейна. Функииональная диагностика. 2010. № 3. С. 67.

16. Петрова Т. Б. Изменение параметров углеводного обмена у плавсостава Северного водного бассейна. Экология человека. 2009. № 8. С. 12-18.

17. Симоненко В. Б., Александров А. С., Дулин П. А. О структуре заболеваемости патологией органов пищеварения у моряков. Военно-медичинский журнал. 2008. № 4 (329). С. 58.

18. Бойко Е. П. Гемодинамические сдвиги у моряков при плавании в тропических широтах. Кардиология. 1973. № 5. С. 140-141.

19. Сапов И. А. Некоторые физиологические и медицинские аспекты адаптации. Морской меди иинский журнал. 1998. № 6. С. 24-29.

20. Конвенція Організації Об'єднаних Націй з морського права : Конвенція, Міжнародний документ від 10.12.1982. Відомості Верховної Ради України. № 728-14. Ст. 90-92.

Orlova Nataliia. Features of legal regulation of labor protection on water transport

The article is devoted to the study of features of legal regulation of labor protection on water transport. The most common causes of water transport accidents have been analyzed. It is noted that presence of the required number of crew members on board affects the observance of working hours requirements, preventing overload of crew members, providing proper rest time. It is emphasized that the differentiation 
of legal regulation of working time and rest time of water transport employees is carried out on three grounds: the operating mode of the ship, design features of the ship, the nature of labor functions of the crew. In order to ensure that the crew's duration does not exceed a safely acceptable level, the owner of the ship should determine the list of necessary and sufficient functions that must be carried out on board during the upcoming voyage, functions that can be combined in normal operation of the ship and in case of emergency situations on board and the minimum composition of the crew, that is necessary for the safe performance of functions in combination. The opinion is maintained that checking the health status of water transport employees is one of the guarantees of safe shipping. The level of professional suitability of ship's specialists directly affects the duration of their work experience without significant changes in the state of the triad - "health / working capacity / reliability", therefore regular monitoring of the health status of employees is a guarantee of personal and collective safety on water transport. It is proved that any ship should be headed by a captain and should be managed by suitably qualified employees who, due to health reasons, are suitable for working on water transport; the crew must correspond with the type, size and equipment of the ship. It is concluded that the specifics of the organization of labor protection of crew members during the voyage is that the risk is created not only by production factors, but also by climatic conditions, the possibility of infection in ports, the threat of being taken into pirate captivity etc. The necessity of proper legal regulation of the protection of life and health of crew members during work and outside the work is substantiated.

Key words: water transport, water transport employee, accident, labor protection, crew, health status. 